\title{
MONITORING OF HELICOPTER SWASH-PLATE WEAR USING THE FAM-C DIAGNOSIS METHOD
}

\section{Andrzej GĘBURA, Henryk KOWALCZYK, Tomasz TOKARSKI, Kacper HANDZEL, Slawomir Jerzy KLIMASZEWSKI, Franciszek ZGRZYWA}

\author{
Air Force Institute of Technology, 01-494, Warszawa 46, Księcia Bolesława 6, \\ e-mail: andrzej.gebura@itwl.pl
}

\begin{abstract}
Helicopter rotor dynamics (blade vibrations, ground resonance, influence of forward speed, etc.) play an important role in the wear and tear of the transmission system and power unit. Particularly fast wear of these components is to be expected in military helicopters in combat conditions, where the flight dynamics parameters are often exceeded. The FAM-C method developed at the Air Force Institute of Technology in Poland has been used to assess and monitor this wear. This method can be used to monitor damage to helicopter propulsion and transmission, where other "classical" methods are less effective due to a very complicated system of forces, variable as to the direction of amplitude and frequency, causing vibrations in closely spaced kinematic pairs. For this reason, vibroacoustic and thermal effects are created around these kinematic pairs, which interfere with each other. In a helicopter, the propulsion unit, including the power transmission unit, is at the same time the carrier unit. This has forced designers to construct a propulsion system with a much greater number of joints and bearing supports. This article presents the possibilities of the FAM-C method for monitoring of swash-plate main bearing wear. The swash-plates are not formally part of the helicopter's propulsion unit but are used to direct the thrust vector of the blades i.e., they direct the helicopter's power vector. Since during this process their components are observable by the FAM-C method, the authors found it necessary to include issues related to their diagnosis in this study. In the FAM-C method, the signal from the AC generator during the normal operation of the helicopter is processed. Analysis of this signal allows simultaneous monitoring of multiple engine and transmission components simultaneously. It does not require any separate sensors for this purpose - one "full-time" alternator or tachometer generator is - with proper collection and processing of the output voltage signal - the source of a whole range of diagnostic information. Thus, one generator is an observer of the technical condition of many elements of the power unit simultaneously. What's more, the signal can be collected from any place in the electrical network, which makes it possible to install the measuring system in safe locations, even while the power train is running. Some examples of diagnostic symptoms leading to wear detection are described. Research based on analysis of these findings with the use of the FAM-C method is described in the paper. In the FAM-C method, signal from the AC generator used in routine operation of the helicopter is processed. Signal analysis enables simultaneous monitoring of several engine and transmission elements. Some examples of diagnostic symptoms used to detect wear are described in the paper.
\end{abstract}

Keywords: frequency analysis, blade tip timing, bearing wear, gear wear, alternator, frequency modulation, power transmission, characteristic pattern, helicopter swash- plate.

\section{INTRODUCTION}

Helicopters are specific aircraft. Their lifting power is generated by rotating blades called carrier rotor(s), and the rest of the aircraft is, as it were, suspended from the axis of rotation of the carrier rotor(s). This generates a unique role in ensuring flight safety for a set of interconnected components consisting, in addition to rotors, of hubs, gears, shafts and engines with their installations. Sometimes the name carrier-propulsion unit is used for this set of elements. This, in turn, forced designers to design solutions with a much greater number of joints and bearing supports than on other aircraft. As a result, there is a much greater number of kinematic pairs in a helicopter than in an aircraft. They generate both vibroacoustic waves and thermal spectrum, but due to the proximity of their location, they interfere with each other. Sometimes, because of interference signals may even be mutually attenuated at the sensor location. Increased level of vibrations from this complicated structure forced the constructors to use solutions "absorbing" vibrations, such as massive casings or special supports. As a result, vibroacoustic and thermal signals from many kinematic pairs are suppressed. This results in significant difficulties in diagnosing power transmission components and the helicopter control system using vibroacoustic and thermal methods.

(C) 2022 by the Authors. Licensee Polish Society of Technical Diagnostics (Warsow. Poland). This article is an open access article distributed under the terms and conditions of the Creative Commons Attribution (CC BY) license http://creativecommons.org/licenses/by/4.0/) 
Particularly intensive wear and tear occurs during military operations. Operating in a threatening environment, helicopter structural elements work for a long time at the limit ranges and even beyond them. The acceleration amplitudes increase significantly in relation to exercises or even peacetime missions [7, $13,17]$. In order to detect potential threats and components of the helicopter carrier-propulsion unit as early as possible, the FAM-C diagnostic method has been developed and patented in Poland by the Air Force Institute of Technology [9]. The method uses frequency modulation of the angular velocity generated by individual mechanical components (Fig. 1). Each component has an angular velocity, which can be described by the formula:

$$
\omega_{\mathrm{j}}=\omega_{\mathrm{jN}}+\Delta \omega_{\mathrm{j}}
$$

where: $\omega_{\mathrm{jN}}$ - rated angular speed of the component, $\Delta \omega_{\mathrm{j}}$ - angular velocity band - depending on the size of the wear defect of the $\mathrm{j}$-th component.

The on-board electric generator converts the above-mentioned the angular velocity modulations of individual components to the frequency of the voltage modulations:

$$
f_{\mathrm{j}}=f_{\mathrm{jN}}+\Delta f_{\mathrm{j}}
$$

The generator also acts as an adder, which enables simultaneous observation of modulations from many components at the same time:

$$
\Sigma f_{\mathrm{j}}=\Sigma\left(f_{\mathrm{jN}}+\Delta f_{\mathrm{j}}\right)
$$

This method makes it possible, among other things, to diagnose one of the most heavily loaded elements of a helicopter - the swash-plate. This very complicated part of helicopter control system, located in or near the main rotor hub, transmits the movements of the control stick and the general pitch lever to the rotating blades [13, 17]. Invented by B.N. Yuriev in 1911, the swash-plate is a mechanism for changing the angle of the blades and, as a result, the direction of the resultant aerodynamic forces of the main rotor [17] and is currently used on all helicopters. Diagnosing it with "classical" methods is less efficient due to the very complicated system of forces and mutual interference of vibrationacoustic and thermal effects. The FAM-C method analyses the signal from the onboard AC generator during normal helicopter operation. This makes it possible to monitor multiple engine and transmission components simultaneously. In comparison, the "classical" vibroacoustic and thermal methods as well as the existing TTM methods require a separate sensor to be installed at each kinematic pair. FAM$\mathrm{C}$ does not require any separate sensors - only an onboard alternator or tachometer is the source of a whole range of diagnostic information about multiple kinematic pairs simultaneously, thanks to appropriate collection and processing of the output voltage signal. Thus, a single alternator is an observer of the technical condition of many elements of the power train simultaneously, hence the working name "alternator- converter" used by the authors. Moreover, the signal can be collected from any point of the electrical network, as the frequency modulation of the on-board network voltage is the same at all points of the aircraft electrical network, in contrast to the amplitude modulation, which is subject to attenuation. This allows the measuring system to be installed in safe locations. Connecting the FAM-C measuring apparatus is possible even when the power unit is running. The article describes some examples of wear diagnostic symptoms of swash-plate components using the FAM-C method, which were then verified by mechanical measurements during disassembly of these components.

\section{GENERAL DESCRIPTION OF THE FAM-C METHOD}

The FAM-C method was developed at Air Force Institute of Technology and was initially (1990) applied to diagnose the dynamics of the ground power unit LUZES used to powering onboard aircraft systems [9].

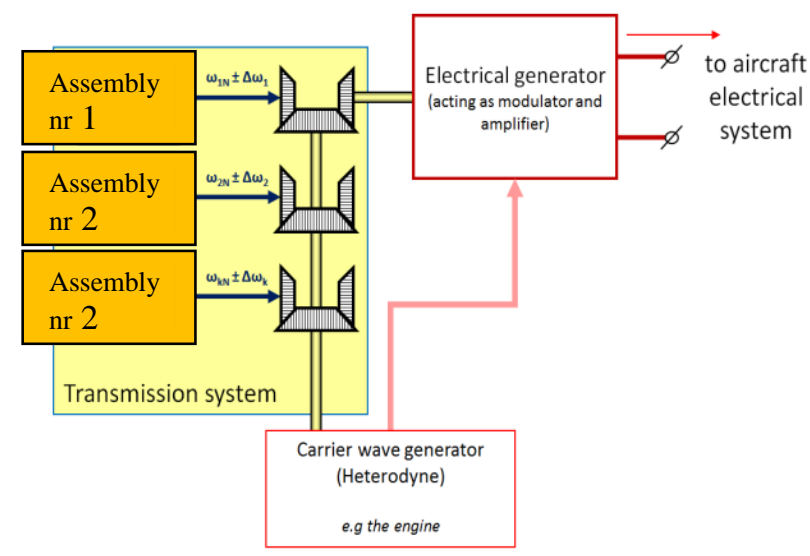

Fig. 1. Block functional diagram showing synchronous representation of mechanical phenomena in the FAM-C method

FAM-C is in essence a Tip-Timing Method (TTM) $[1-2,4,16]$. TTMs are based on indirect measurement of angular velocity and displacement of rotating elements (e.g. turbine blades) with the use of electromagnetic, optical, microwave or capacitive sensors. The FAM-C method uses the Time of Arrival (TOA), which is one of the TTM subtypes and was described by Campbell. In contrast to the classic tip timing, the FAM-C doesn't require installation of any additional sensors as it uses the regular, on-board alternating current electric generator (see schematics on Figure 1) [10]. Each generator pole serves as a reluctance sensor which observes the rotation of the generator's rotor grooves. Because the generator poles are equally distributed on the circumference, and their number is different to the number of rotor grooves, the negative impact of measurement aliasing is mitigated. Also, since the cross-section area of the generator rotor teeth and stator poles is greater than those of turbine blades or gear teeth used as modulators in the classic 
TTM, the saturation of the metallic elements is less problematic.

The generator teeth are made of high magnetic saturation point materials - therefore, in practical circumstances, the generator manifests a linear magnetization character. In addition, the generator introduces small phase measurement error because of the significant rigidity of the generator rotor elements (which serve as a modulator of the diagnostic device) - i.e. the precision of generator rotor teeth spacing is very high, especially in comparison to the tolerances used for spacing of engine compressor blades. The spacing between teeth remains stable during the measurement process, while it changes in the case of compressor rotor blades. The cores of generator's magnetic circuits are composed of chrome plate packets which gives a significant resistance to eddy currents.

\section{FUNCTIONAL DESCRIPTION OF A SWASH-PLATE IN A HELICOPTER CONTROL PROCESS}

The swash-plate is the most complex part of a helicopter's control system. It is located in or near the main rotor hub. Its function is to transmit the movements of the control stick and the pitch lever from non-rotating to rotating parts. It is a mechanism enabling the change of blade angle and, as a result, of the value and direction of the resultant aerodynamic forces of the main rotor [13, 17]. The change of the resultant force value is achieved by changing the overall pitch of the main rotor, i.e. by increasing or decreasing the angles of all the blades by the same value. The pilot performs this action by pulling (upwards) the pitch and power lever on the left side of the seat of the first and second pilot). The lever, through a system of linkages, acts on a hydraulic amplifier (Fig.2, item 1). The amplifier moves fork 2 of the general pitch lever in the swashplate assembly. This causes vertical displacement (along the main shaft axis of symmetry) of the slider (Fig. 2, item 11), upward displacement of the main bearing (Fig. 2, item 9). This bearing causes upward displacement of the movable (Fig. 2, item 3; Fig. 3, item 5). This causes displacement of the pushers (Fig. 2 item 4; Fig. 3, item 4) which increase the angle of attack of all the blades simultaneously. As the angle of attack of the blades increases the lifting force increases, and the helicopter begins to climb. Solutions of Soviet-manufactured helicopters operating in Poland and widely represented in the aviation of the Polish Armed Forces were analysed. The Mi-8, Mi-14, Mi-17, Mi-24 should be mentioned here. Since western technology is likely to enter the Polish Armed Forces more and more often, it is worthwhile, in the further development of this method, to analyse the differences in solutions from both sides of the former "Iron Curtain", such as:

1. Reverse direction of main rotor blade rotation between eastern and western standards.
2. Twice the speed of the so-called western standard.

3. A different standard, or even idea, of hard landing safeguards:

- The eastern standard is based on reinforcing the hull structure under the main gearbox so that, in the event of failure, the existing space there is not crushed by the heavy main gearbox,

- The western standard is based on weakening the hull structure under the main gearbox (sometimes a special hole is left in the floor structure) so that the gearbox can pass through the hull in case of failure, while the passageway is often set aside as a forbidden zone, thus reducing the cargo area.

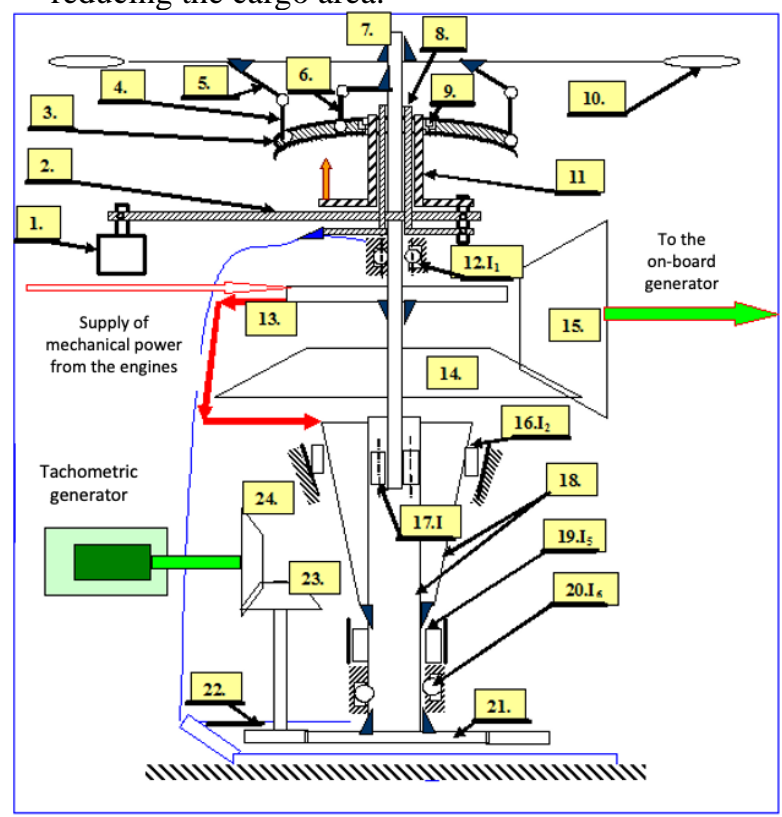

Fig. 2. Swash-plate in the system for transmitting the primary diagnostic signal to the helicopter's generator transducers: 1 - hydraulic actuator of the overall pitch; 2 fork of the overall pitch lever; 3 - disc (upper);

4 - blade pusher (change of blade angle of attack); 5 blade rotation lever (change of blade angle of attack); 6 synchronizer rod (sets the upper disc into rotation synchronously with the angle of rotation of the WR gearbox main shaft); 7 - WR gearbox main shaft with hub; 8 - guide (fixed inner sleeve); 9 - main double row ball bearing ( 46 balls) of the swash-plate - ensures transmission of forces aimed at displacement or tilting of the (upper) disc under the influence of the slider; 10 supporting rotor blade; 11 - slider (movable outer sleeve); 12 - upper bearing of the WR gearbox main shaft; 13 planetary gear; 14 - power take-off cone wheel towards the generator drive box 15 - power take-off cone wheel towards alternator drive box; 16 - taper roller bearing of planetary gear output shaft; 17 - lower main shaft support bearing (gear bearing between main shaft and planetary gear output shaft); 18 - planetary gear output shaft; 19 cylindrical roller bearing of planetary gear output shaft; 20 - planetary gear output shaft thrust ball bearing; 21 planetary gear power transmission spur gear towards the tachometer generator; 22 - planetary gear power take-off spur gear towards the tachometer generator; 23 planetary gear power transmission bevel gear towards the tachometer generator; 24 - planetary gear power take-off bevel gear towards the tachometer generator. 


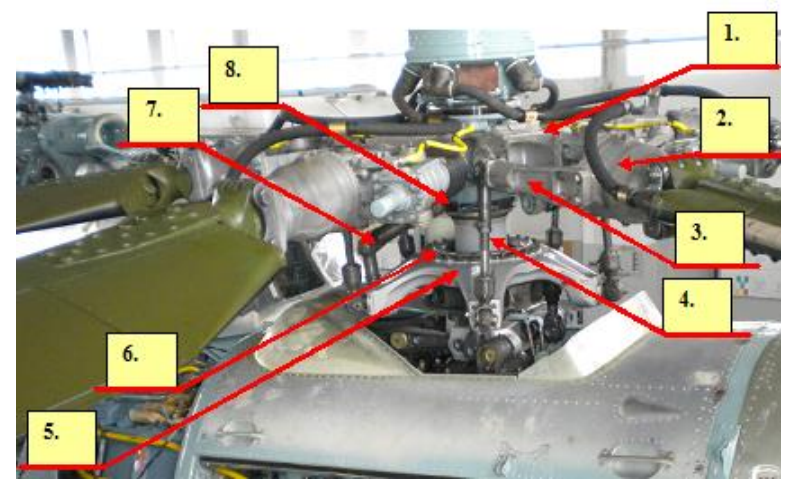

Fig. 3. Mi-24W helicopter swash-plate: 1 - carrier rotor hub; 2 - horizontal joint of the blade (carrier propeller); 3 -4 blade rotation lever; 4 - blade rotation linkage; 5 upper control disc; 6 - main bearing, providing interaction of the lower (stationary) disc with the upper one; 7 - rotating scroll (acting as a kind of steering synchronizer); 8 - bracket (yoke), mounted on the hub body of the carrier rotor causing the pulling of the rotating scroll and setting the upper disk of the swashplate into rotary motion.

4. Use of the inside of the main gearbox shaft: - eastern standard: in the middle of the (hollow) main shaft of the gearbox, a fixed casing pipe is inserted, through which heating cables are led to supply electricity to the blades of the carrier rotor. This makes it possible to electrically de-ice the leading edges of the blades. This makes it possible to fly at low temperatures in icing conditions,

- western standard for light and medium sized helicopters: in the middle of the (hollow) shaft there are usually control cables for the 1 swashplate. This makes it possible to reduce the forces required to steer small and medium helicopters practically without the need for hydraulic amplifiers,

- in Russian designs it is almost impossible to control a medium helicopter when the hydraulic amplifier system fails,

- in western designs the lack of heating of the carrier propeller (nowadays they are installed on special order) is partly compensated by higher flexibility of the blades, which breaks the ice surface. According to practitioners, this is only effective in low-intensity icing conditions.

Point 4 mentions that according to the Russian standard, the inside of the main gearbox main shaft is used as a trough for the electrical cables of the blade heating circuit. Therefore, the control elements must be routed on the outside of the main shaft. This increases the mass of the swash-plate, which by its circumference must encompass the main shaft of the carrier rotor. It also undoubtedly increases the forces (static and dynamic) acting on the swash-plate and, above all, the main bearing of the swash-plate. However, irrespective of whether the control swashplate to be diagnosed is of eastern or western standard, there are two critical components in it, i.e. highly stressed and, in the event of failure, without a 'double':

1. main bearing of the swash-plate,

2. the synchronizer, i.e. the elevator.

Ad. 1. If the main bearing of the swash-plate is damaged, the control process may slow down - it will become imprecise, increased vibrations in the control system may appear. For certain types of damage, increased dynamic shocks in the circumferential motion affecting the synchronizer may occur. This bearing is directly involved in the process of angular displacement of the moving platter of the swash-plate. This operation is often accompanied by considerable drag forces (overcoming the aerodynamic force of the blades when increasing their angle of attack), changing rapidly in time as to direction and value $(0.5 \div 4$ changes per second). This bearing therefore operates in unstable conditions. A similar problem occurs in the case of the main bearing of a wind power plant [14] - increased efficiency of cooling with lubricating oil is recommended there. In the swashplate, which is assumed to move axially (along the supporting rotor shaft) and angularly, the supply of lubricating oil is not possible. Moreover, this bearing is influenced by significant radial forces from the unbalance of blades - already at average radial clearances operational problems may appear, which are classified in the rolling bearing theory as the influence of misalignment on the stress distribution inside the bearing [3, 9, 12, 14] - only effective diagnostics remains.

Ad. 2. The synchronizer (Fig. 3, item 7) connects the (upper) disc of the swash-plate with the main shaft of the transmission (here, for example, WR24). This ensures that changes in the angle of attack of each main rotor blade are synchronized with its azimuthal position relative to the longitudinal axis of symmetry of the helicopter fuselage. The synchronizer consists of three rods forming a trapezoidal shape. Four of its joints have needle bearings. The upper arm is fixed near the upper end of the main shaft just under the lifting rotor head for this purpose the designers used a strongly clamped clamp on the shaft.

A shallow hole has additionally been milled on the main shaft to allow a pin connection to the synchronizer clamp. However, significant peripheral clearances were frequently experienced at this particular location, as well as at the synchronizer joints. This forced them to replace the synchronizer immediately. Increased circumferential play of the synchronizer is a handicap for the pilot. A sheared pin, on the other hand, is a certain disaster - the helicopter loses the ability to synchronously azimuthally direct changes in the angle of attack of the blades as they move in the horizontal plane. The 
pilot will then be able to control the amplitude of the angles of attack but will lose influence on the direction of flight. Depending on the balance of the blades and other control mechanisms, an attempt, for example, to tilt the helicopter by giving up the stick may manifest itself as a sideways or backwards tilt or a rotational movement.

Damage to rolling bearings can be of various types depending on deviations of their fits in the manufacturing or overhaul process [5, 9-10], and also depending on the operating conditions. One of the most important parameters is the current value of the rolling bearing coefficient. Physically it is the ratio of the cage speed to the rotational speed of the moving raceway, denoted as $p_{\mathrm{s}}[9,10]$. In all analyses this current value must be compared to the nominal value determined from the geometrical data of the given bearing. The nominal value of the rolling ratio is determined from equation 4 . The dimensional data for the equation are shown in fig. 4 . For the Mi-24 helicopter example, this value is $\mathrm{p}_{\mathrm{sN}}=$ 0.47356 .

The effect of backlash causes indents on the curve of the instantaneous angular velocity $\omega_{2}=f(t)$ on the falling slope of the sinusoid (Fig.5) [9]. On the basis of many laboratory tests on the LUZES III drive unit and computer simulations, the authors concluded that the relative depth of the above-described indentations in the rising slope of the course $f_{i}=f(t)$ and duration of the above-mentioned indentation on the falling slope is directly proportional to the backlash value [9]. According to the authors, these relationships could be used to observe the degree of loosening of articulated joints of rotating scroll and the backlash of the synchronizer yoke connection with the main shaft and the main rotor head.

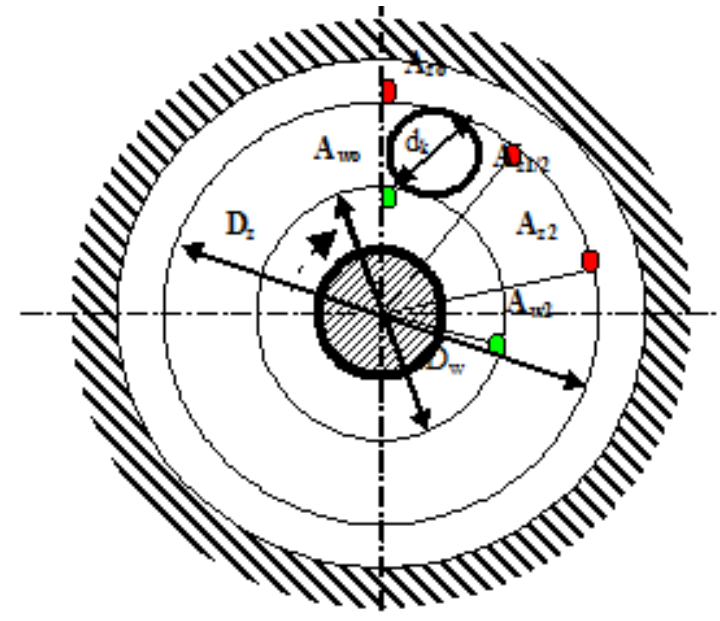

Fig. 4, Overview drawing of a rolling bearing displacement of the bearing cage relative to the inner raceway, where: $\mathrm{D}_{\mathrm{w}}$ - diameter of the inner race (for $\mathrm{Mi}$ $24 D_{w}=283 \mathrm{~mm}$ ); $D_{z}$ - diameter of the outer race; $d_{k}$ diameter of the rolling element (for Mi-24 $\mathrm{d}_{\mathrm{k}}=7.9 \mathrm{~mm}$ )

$$
p_{s N}=\frac{D_{w}}{2\left(D_{w}+2 d_{k}\right)}
$$

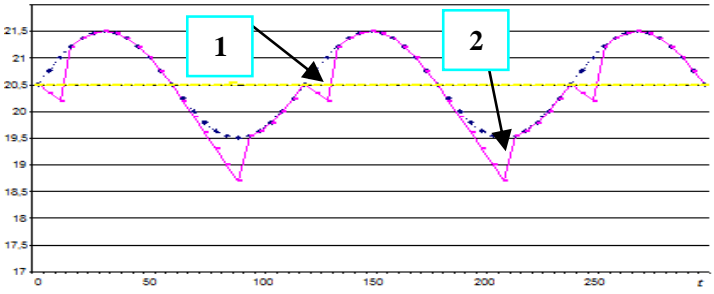

Fig. 5. Theoretical course of changes of instantaneous values of: rotational speed $n=f(t)$ and frequency for a coupling with eccentricity defect and backlash: 1 indentation on the rising slope, 2 -indentation on the falling slope

To determine the value of the current rolling factor it is necessary to mark on both bearing rings with a marker one common mark on the moving ring (usually the inner ring) and the bearing cage. By turning the moving ring (e.g. the upper disc of the swash-plate) of the unit you observe the relative movement of the mark on the cage against the mark on the moving ring. A more accurate measurement may be obtained by turning the movable race until the cage makes one complete revolution - then the angle traced by the movable race should make several revolutions equal to the reciprocal of the value determined by formula (1).

The cooperation of rolling elements with the raceway during normal (operational) operation of the complete device can be precisely observed using the FAM-C method [10].

In the present diagnostic tests of bearing nodes of turbojet engines SO-3 of TS-11 Iskra aircraft, the rolling factor was calculated from the ratio of the maximum frequency fpmax of the band occupied by the characteristic set of a given bearing to the frequency of the $\mathrm{N}$-th harmonic, where $\mathrm{N}$ - the number of rolling elements of a given bearing. During testing of aircraft turbine engine bearing nodes, original characteristics of the rolling coefficient $\mathrm{p}_{\mathrm{sN}}$ as a function of rotational speed were obtained. Similar characteristics could be obtained for the main bearing of the swash-plate at different rated speeds of the main rotor shaft, even though the range of speed variations possible on a helicopter is much smaller than for aircraft. For helicopters it is $\pm 10 \%$ of the rated value, while for turbojet aircraft engines it is $200 \div 300 \%$.

\section{MECHANICAL PROBLEMS RELATED TO OPERATION OF THE SWASH-PLATES}

Whether the swash-plate is of eastern or western standard, there are two critical points in it, namely: 1. the main bearing (Fig. 2, item 9; Fig. 3, item 3), 2. the synchronizer (Fig. 3, item 7).

According to the theory of automatics, the occurring slack in the control system causes a delay in the reaction of the actuators. In the case of helicopter control, it is the delay of the instantaneous value of the blade angle of attack $\alpha$ in relation to the deflection of control elements by the pilot (pitch and power lever and the general pitch lever) $[13,17]$. 
At the same time, it should be noted that if the sequence of the helicopter's control elements (rods, pushrods, rocker arms, joints, swash-plate bearing) has no play at the joints, then from the point of view of vibration theory they together constitute an element of considerable length, and therefore of low natural frequency. If there is non-normative play at the joints, this whole sequence of control elements breaks up into many short elements - the break-up into individually oscillating elements then takes place [9]. From now on each such short element vibrates in separation from the others. Short elements mean a higher natural frequency. In general, helicopters have much higher vibration frequencies than aeroplanes due to their specific design. As soon as the frequency of the local vibration source equals the natural frequency of the component, resonant excitations of these helicopter components may occur, e.g. between the engine input shaft and the swash-plate bearing [9]. Prolonged residence of the rolling bearing in a state of resonance can significantly shorten the service life of the entire swash-plate. It is therefore an operational problem that can significantly shorten the life of the swash-plate. The first case is a pilot problem, especially when performing a fast maneuver. The speed of response to the displacement of the control stick is particularly important for combat helicopters, especially when flying close to the ground surface (more effective position masking) or combat turns.

The service life of this bearing is additionally shortened with dynamic changes in direction and force of its load during steering. This is due to:

(a) changes in direction (turn) and changes in the value of the force acting on the bearing. The bearing can be variously loaded in different regions of its circumference, which leads to different wear - the bearing can be [10]:

1) clamped - wear model with reduced radial clearance,

2) loosened together with optimum clearance conditioning resonance occurrence,

3) with increased joint resistance including blocking of rolling elements between raceways;

(b) alternating stress dynamics:

1) pulsations resulting from periodic control occurring even during flight at a fixed progressive speed, i.e. during straight flight;

2) impulses: explosive (overloading of the rolling bearing structure) of considerable amplitude and steep slope,decay pulses (rolling element bearing underload) with significant amplitude and steepness of slope;

c) significant moment of inertia of the main rotor blades; helicopters have low main rotor angular velocities (of the order of $2 \div 4 \mathrm{rpm}$ ); the same low angular velocity must have (synchronized with the above mentioned main rotor) the swash-plate. Low angular velocity means a delayed reaction of the main bearing of the swash-plate to the excitation by the control system $[3,15,17]$; (d) the significant force required to drive the main supporting rotor assembly. The main bearing of the swash-plate often operates in strong skews, which eliminates the use of roller bearings (their design allows small skews, only about 20 angular $\min$, while for ball bearings $\beta \max =1.50$ and more). Therefore, designers are forced to mount bearings with an increased number of bearing balls. However, an increased number of rolling elements is also a delayed reaction of the main bearing to the forcing by the control system [3, $15,17]$

e) fixing only the lower part of the swash-plate structure (with a relatively high height), while it is the upper elements that are affected by the reaction force of the supporting blades, which causes secondarily significant static and dynamic forces.

\section{OPERATIONAL PROBLEMS RELATED TO THE MAIN BEARING OF THE SWASH-PLATE}

The main bearing of the swash-plate, as noted in subsection 3, has two very important functions:

a) separates the movable swash-plate from the stationary pivot,

b) takes over the angular pressure of the journal.

The resonance of this bearing is almost imperceptible to the pilot (as in a parallel electric resonant circuit, the increased energy of the resonant vibrations of RLC parallel system remains inside the system). The energy of resonant vibrations causes destruction to its internal components (Fig. 6), in the form of (in order of severity of destruction) [9, 10]:

1. false Brinell's indentation,

2. damage to the running surface,

3. surface defects on rolling elements,

4. rupture of the cage-separator circuit (Fig. 6, elements 3 - 5),

5. damage to the simmering ring protecting the main bearings against the ingress of dirt and water,

6. the ingress of external contaminants (after simmering ring breakage) and water into the bearing results in corrosion phenomena - the bearing joint resistance increases, increased abrasive processes begin,

7. leakage of grease outside the swash-plate intensification of abrasive processes inside the bearing, increase in temperature of rolling elements (potential fire hazard - alloy of the body of the moving swash-plate is made of magnesium casting which self ignites at increased temperature),

8. increased radial and longitudinal clearances causing:

- increased probability of resonant structural coupling in the mechanical power transmission unit,

- a delayed reaction of the helicopter to the movement of the rudder stick. 


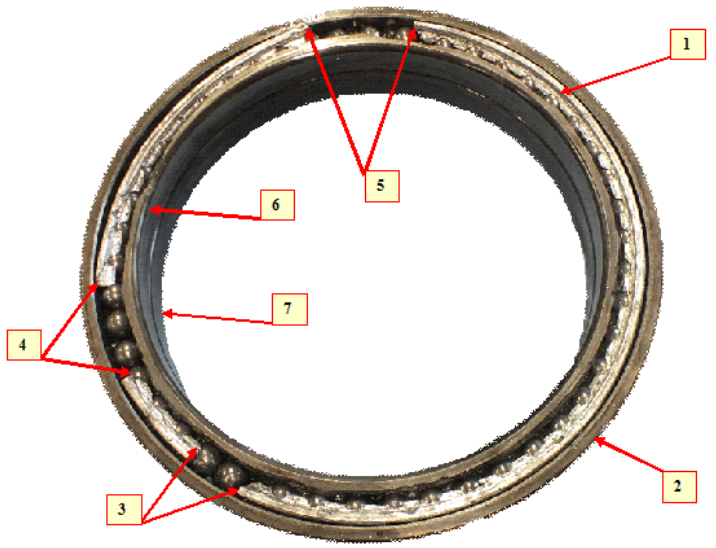

Fig. 6. Main bearing of the swash-plate after long-term operation in resonance condition with visible broken cage-separator (losses in three places): 1 - cage-separator (aluminium alloy); 2 - outer ring of the main bearing (common for the upper and lower row of rolling elements; 3, 4, 5 - tears in the cage-separator circuit; 6 inner raceway of the main bearing; 7 - lower inner halfring of the main bearing

Cases of failure of the main bearings of the swash-plates are rare - the manufacturers, realizing their exceptional importance for flight safety, have provided for their relatively frequent replacement. In addition, bearings of this type are specially mounted, in a way that allows long-term operation in conditions of strong vibrations (fig. 7):

1. The inner race of the bearing is bipartite - there are two half rings:

(a) lower (fig.7, item 17),

b) upper (fig.7, item 15).

2. The inner raceways of the bearing are slightly inclined - both raceways have a surface in the shape of two cones connected by bases. In this way, when large axial forces occur, the bearing has the possibility to obtain a small clearance which prevents its rolling elements from jamming (fig. 7, elements 12,13).

3) The bearing rings are pressed from above by a nut (Fig. 7, item 10), screwed on the upper part of the journal (Fig. 7, item 1), through two spring pressure rings; after each overhaul these rings are replaced by brand new ones, after which the helicopter is directed for a fly-over. After the helicopter is flown, the nut is retightened.

4) Ball bearings are used because they are the only ones capable of transmitting longitudinal forces and operating with significant journal skew.

5) Bearings with a large number of rolling elements are used to ensure a sufficiently high bearing load capacity.

6) Light alloys (aluminum matrix) cage-separators are used; low mass of own parts means lack of significant moment of inertia during vibrations of rolling elements - influence of vibrating rolling elements on cage windows is minimal - under ball impact the cage removes with almost no resistance. During operation, the main bearing of the swash-plate is affected by numerous forces that vary in direction and value, including:

1. longitudinal forces (along the carrier rotor shaft) associated with helicopter steering, i.e. between the lower part of the journal (Fig. 7, item 3) and the lower ring of the main bearing (Fig. 7, item 17). Then, during the initial period of such a maneuver, there are significant forces acting on the pressure rings. Therefore, when the rudder rod is tilted, e.g. to the left, the right side of the pivot presses on the upper bearing fixing structure (including the elastic pressure rings) on the right side. Particularly high pressures from this side, as mentioned, occur at the first moment after the rod is tilted, as the system overcomes the inertial forces associated with moving the carrier blades. At this time, the less loaded left side of the bearing and its elastic rings (Fig. 7, elements: 11, 14; Fig. 8; Fig.9), within its radial and longitudinal clearances, may perform some vibrations causing surface abrasion. If the longitudinal clearances in the bearing are significant, the abrasion of pressure ring faces becomes more intensive as well. Due to the nature of the task, the helicopter rarely flies backwards - hence the abrasion of the spring pressure rings may be asymmetrical. If the overhaul company uses worn spring compression rings (only coating with a layer of chromium which covers the original compression ring evenly and does not regenerate the obliquely worn surface), then with asymmetrical wear of the front surfaces of these rings (Fig. 8 and9), slippage may occur even in horizontal flight of

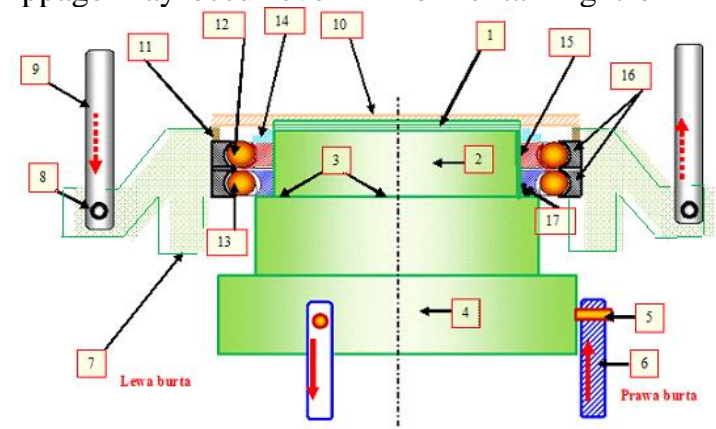

Fig. 7. Main bearing in heavy steering swash-plate arrangement: 1 - upper pivot; 2 - pivot; 3 - lower pivot; 4 - outer Cardan frame; 5 - upper pivot of the tilt angle

8 pendulum connecting (movably) the tilt angle pendulum to the outer Cardan frame with the tilt pusher; 6 - tilt angle tappet; 7 - movable swash-plate; 8 - pin connecting the blade tapet to the end of the movable swash-plate arm; 9 - blade tappet; 10 - main journal nut (pressing the rings against the raceway); 11 - elastic pressure ring of outer raceway (outer ring) of main bearing; 12 - rolling element in the upper row; 13 rolling element in the lower row; 14 - elastic pressure ring of inner raceway (inner ring) of main bearing; 15 upper inner half-ring of main bearing; 16 - outer ring of main bearing (common for upper and lower row of rolling elements); 17 - lower inner half-ring of main bearing 
the thus "reconditioned" pressure rings (Fig. 7, elements: 11,14) against the main bearing rings (Fig. 7 , elements: 15,16$)$ of the newly reconditioned swash-plate.

2. radial forces - during flight, the swash-plate, and especially its rolling bearing, is subjected to significant radial forces related to:

- unbalance of the main rotor,

- radial run-out of the main gearbox shaft.

These forces cause a significant rate of increase of radial clearances (higher than in rolling bearings of other helicopter components). At a certain (optimum) radial clearance, resonance of the main bearing may occur [5, 7-9].

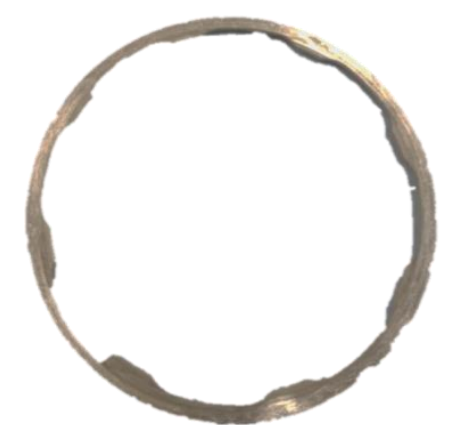

Fig. 8. Inner raceway follower ring of the main swashplate bearing (removed from the bearing seat) from a set of damaged swash-plates - visible material defects.

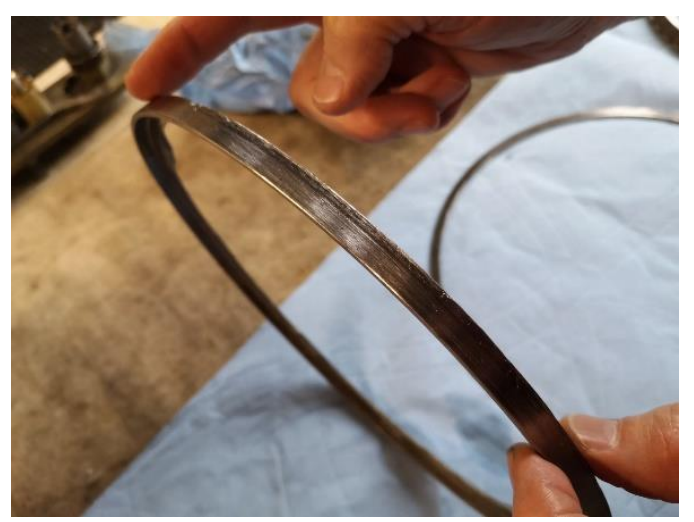

Fig. 9. Photo of a outer raceway pressure ring of the main swash-plate bearing (removed from the bearing seat) from a set of damaged swash-plates; one can see mechanical damage on the edges of the ring caused by the interaction with the resonating main bearing of the swash-plate.

\section{BASIC INFORMATION ON THE FAM-C METHOD}

As mentioned in Chapter 1, the FAM C method uses the processing properties of angular velocity variations of the mechanical components of the helicopter drive unit to modulations the frequency of the on-board electric generator. Mechanical and electrical signals are synchronized with each other this is possible thanks to:

a) Rigid elements of transmission of mechanical movements to the generator-converter - Fig. 1; b) Synchronous properties of the on-board generator [9] - Fig. 10.

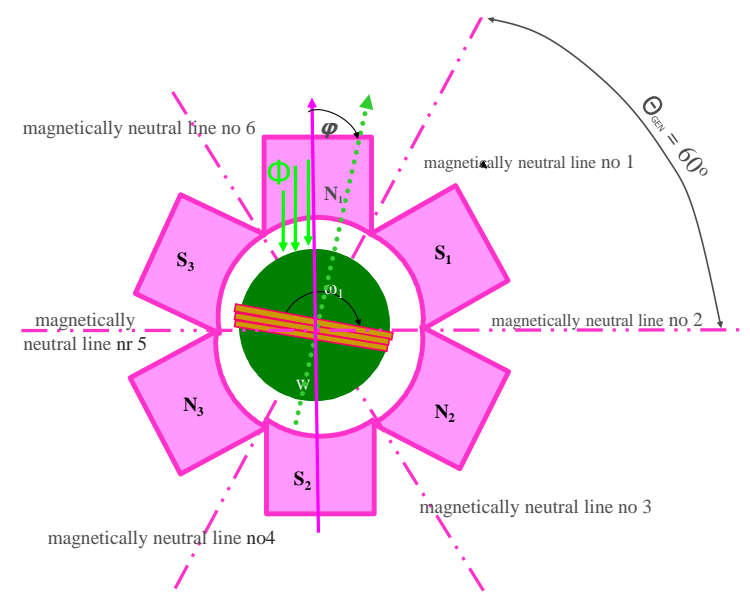

Fig. 10. Alternate current generators with three pairs of poles: $N_{1}, N_{2}, N_{3}, S_{1}, S_{2}, S_{3}$ - the magnetic poles of the stator of the generator, $\varphi$ - momentary angular position of the rotor of the generator, $\Phi$ - the magnetic flux of the stator, $\theta_{\mathrm{GEN}}-$ the angle between the lines of magnetically inert generator stator

Each angular fluctuation of the $\mathrm{j}$-th mechanical component - Fig. 11a, the $\omega_{\mathrm{m}}$ waveform (solid brown line, with local deviation amplitudes: $\Delta \Omega_{1}, \Delta \Omega_{2}$ ) generates changes in frequency modulation - Fig. $11 \mathrm{~b}$, green line. The authors use the synchronism of the generator rotor's passage through the magnetically neutral zones forming the nodes to cross the zero level of the generator's output voltage. Thus, a discrete transformation of angular velocity fluctuations of the $j$-th mechanical component is performed into a discrete waveform of the instantaneous frequency - Fig. 11a (blue dashed line, with local deviation amplitudes: $\Delta \mathrm{F}_{1}, \Delta \mathrm{F}_{2}$ ). These waveforms marked with $\mathrm{f}_{\mathrm{i}}=\mathrm{f}(\mathrm{t})$ provide important information about the energetically dominant fluctuations in the angular velocity in a given mechanical drive unit - Figs. $12 \div 14$, and thus provide data on the technical condition of the most worn or damaged mechanical component. Typically, in a mechanical drive unit, the diagnostician wants to monitor many components at the same time, not just the most worn component. Therefore, the authors developed a proprietary algorithm for decomposing of the waveform $f_{i}=f(t)$ into characteristic sets, consisting of characteristic points - Fig. 11c, points marked with an asterisk. Each such point reflects the successive deviation of the waveform $f_{i}=f(t)$ from the mean frequency. The authors assigned two parameters to each deviation:

a) duration of the deviation: $t_{\text {odch } 1}, t_{\text {odch } 1}, \ldots$;

b) the amplitude of the deviation $\Delta \mathrm{F}_{1}, \Delta \mathrm{F}_{2}, \ldots$.

During the FAM-C measurements, the characteristic points create for individual mechanical drive units of the tested helicopters characteristic sets grouping around the rated frequencies $f_{j N}$ of individual components. As mentioned in section 1, each characteristic set reflects the technical condition of a different mechanical component. 


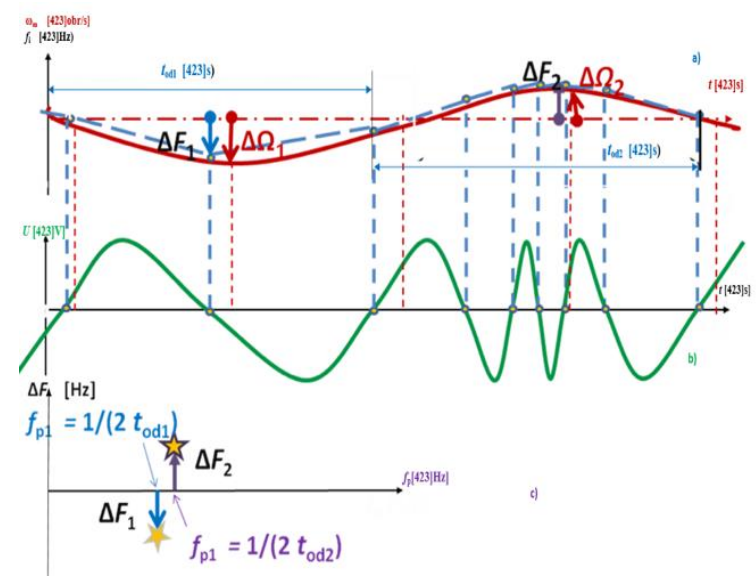

Fig. 11. Transformation of the angular velocity fluctuations signal into changes of the instantaneous frequency of the generator output voltage - successive phases of transforming the instantaneous angular velocity signal (frequency modulated depending on the technical condition) of a given mechanical component into a characteristic set reflecting the technical condition of this component: a) changes of the waveform of the angular velocity of the shaft $\omega_{\mathrm{m}}=\mathrm{f}(\mathrm{t})$ - two examples of deviations of this waveform from the mean value of $\Delta \Omega_{1}$ and $\Delta \Omega_{2}$ (solid red line) are presented; changes of the waveform of the value of the instantaneous frequency $\mathrm{fi}=$ $f(t)$ - two deviations of this waveform from the mean value of $\Delta \mathrm{F}_{1}$ and $\Delta \mathrm{F}_{2}$ (blue dashed line) are presented as an example; $t_{\text {od } 1}, ; t_{\text {od } 2}$ - duration of the deviation of the instantaneous frequency waveform from the average

frequency; b) waveform of the on-board generator output voltage $u=f(t)$ - frequency modulation of this voltage reflects the technical condition of the mechanical component (solid green line); c) method of creating characteristic points on the plane $\Delta \mathrm{F}=\mathrm{f}$ (fp) - each point corresponds to one deviation of the instantaneous frequency waveform $\mathrm{fi}=\mathrm{f}(\mathrm{t})$ from the average frequency.

\section{WEAR MONITORING OF THE MAIN ANTI-FRICTION BEARING OF THE SWASH-PLATE BY THE FAM-C METHOD}

The main bearing of the swash-plate, when given a sufficiently large radial clearance, is sensitive to resonant excitations. As mentioned earlier, these clearances come from several sources:

- blade unbalance,

- vibrations of the main shaft and a worn main gearbox top bearing,

- vibrations of the shaft connecting the turbine engine to the main gearbox,

- slips on the obliquely worn spring planes of the follower rings (Fig.8) during fast maneuvers.

It is well known that resonant excitation of a component occurs when the frequency of the vibration source (another component) equals its own frequency. It should also be added that the excitation may occur without the two values (the eigenfrequency of the object in question and the source frequency) being exactly equal:

a) when the goodness of the mechanical component in question is low - the natural frequency band is widened, b) with harmonic distortion of the interfering signal - instead of one frequency of the interfering signal, there is a whole set of harmonics resulting from Fourier distribution of the distorted signal [14],

c) at occurrence of single impulses, e.g. rotational speed with significant steepness of the slope and significant amplitude.

Resonances of the main rolling bearing of the swash-plate are easy to detect with the FAM-C method - the characteristic set of this bearing then breaks up into several subsets (even eight subsets have been recorded), which decrease their height. When entering the resonance state, the value of goodness Q clearly increases. During the long-term operation of a rolling bearing in the resonance state with the goodness $Q>11$, calculated from the characteristic sets, there occur, among others, strong impacts of the rolling elements against the edges of the cage windows [9-11]. These forces can cause the cage separating elements to break out. "(...) until recently the influence of quality, i.e. shape and dimension accuracy of cages on bearing reliability was underestimated (...)" [5, s. 53].

However, it is known that at high bearing rotational speeds, rapid accelerations and vibrations, considerable inertia forces and gyroscopic moments of rotating rolling parts are released. In the FAM-C method, such breakouts were reflected as a packet of pin pulses (Fig. 12). The number of pulses in the packet is equal to the number of broken out separating elements of the cage. It should be noted that this type of breakouts can even lead to a rupture of the cage circuit.

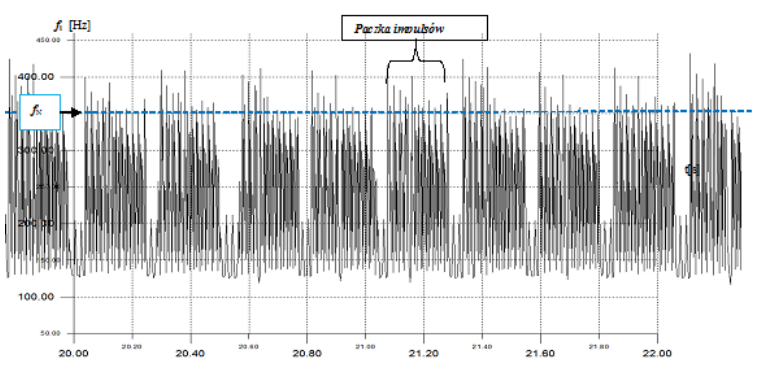

Fig. 12. Instantaneous frequency waveform $f i=f(t)$ of the three-phase FAM-C measurement channel for a bearing that had five separating elements broken off; "packets" of pulses are visible (five-element pin pulse family)

\section{DETECTION OF INCREASED \\ BACKLASH OF A MOVABLE \\ DISCSWASH-PLATE SYNCHRONIZER SPOOL OF A MI-17 HELICOPTER WITH THE FAM-C METHOD}

The synchronization system, as discussed previosly, makes it possible to bring the upper disc of the control swash-plate into synchronous rotation with the main shaft of the main gearbox. This function is carried out by means of a lead whose eye 
is connected to a bracket mounted on the hub body of the carrier rotor, consisting of:

(a) the synchronizer arm (Fig.3, item 8),

b) a swashplate bracket (Fig. 3, item 9) clamped onto the main shaft (Fig. 3, item 1), located just under the main supporting rotor head (Fig.3, item 8).

A shallow hole is additionally milled in the main shaft to allow a pin connection to the synchronizer carrier. However, circumferential clearances sometimes occurred at this particular location as well as at the synchronizer joints. Increased circumferential clearances of the synchronizer are a steering difficulty for the pilot - the periodic control system of the carrier rotor performs maneuvers with a delay and introduces an increased course error. At the same time, increased clearance in this place is the beginning of rapid wear of the pin connection with the synchronizer carrier, eventually leading to shearing of this connection. Cutting off the pin, in turn, is a certain catastrophe - the helicopter loses the ability to synchronously direct azimuthal changes in the angle of attack of the blades as they move in the horizontal plane. The pilot will then be able to control the amplitude of the angles of attack, but will lose influence on the direction of flight. Depending on the balance of the blades and other control mechanisms, an attempt, for example, to tilt the helicopter by giving up the stick may manifest itself as a tilt to the side or rear, or a rotational movement of the helicopter fuselage.

Previously the role of swash-plate was discussed, among other things in controlling the flight geometry of the helicopter. The upper movable part of the swash-plate, the movable disc, is pulled circumferentially by the synchronizer rod [9] (Fig. 2, item 6; Fig. 3, item: 7). Its one end is mounted on the main rotor axis (Fig.3, element 8) and the other end is (articulated) connected to the upper disc of the control swash-plate (Fig. 3, element 5). Increased circumferential clearances of the synchronizer lead may cause difficulties in controlling the helicopter, especially "spontaneous" deflection of the flight course. In an extreme case (e.g. breaking of the mechanical bond between the upper disc of the swash-plate and the main shaft of the carrier rotor), even a catastrophe may occur.

During the monitoring of Mi-17 helicopter by the FAM-C method, undercuts were observed on the descending slope (Fig. 11) - such undercuts occur also in the reference waveform, obtained from a computer simulation (Fig. 5, detail 2) at the time of circumferential play selection. Thus, the instantaneous frequency waveform containing the undercutting is indicative of circumferential clearances occurring between the inertia mass of the helicopter's swash-plate and the generatortransducer.

For comparison, a frequency waveform from another $\mathrm{Mi} 17$ helicopter, not containing the mentioned undercuts, is presented (Fig. 13).

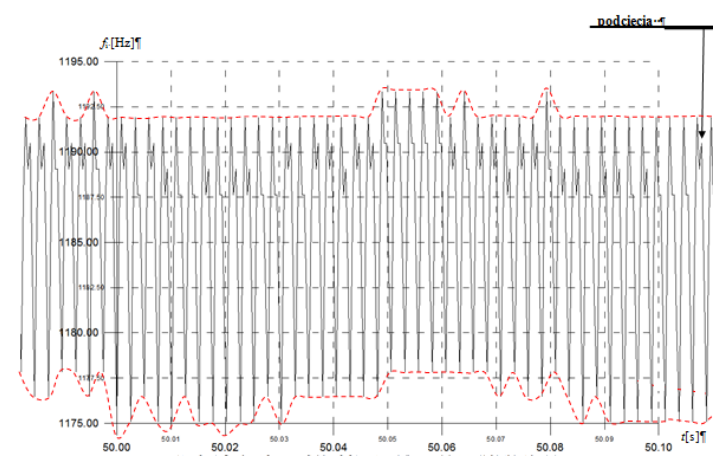

Fig. 13. Transient of instantaneous frequency obtained from three-phase FAM-C measurement from the SGS-

40PU generator from Mi-17 helicopter No. 1; time

window $0.1 \mathrm{~s}$; visible undercutting on the falling slopes of the medium-variable component indicating the circuit clearances.

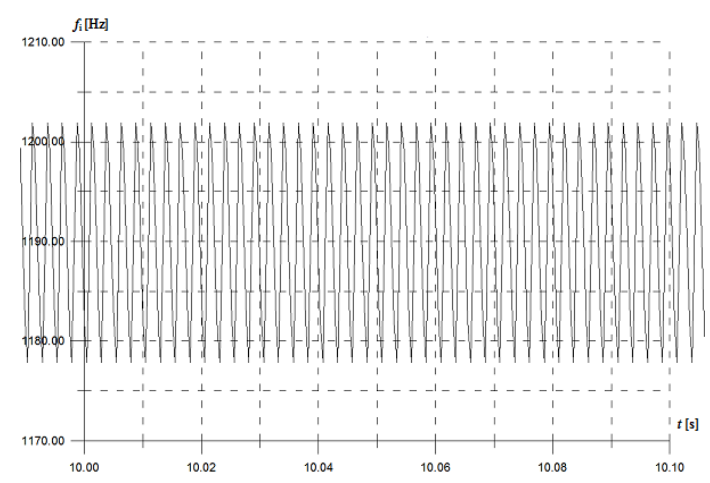

Fig. 14. Transient of instantaneous frequency obtained from three-phase FAM-C measurement from SGS-40PU generator of Mi-17 No. 2 helicopter - time window $0.1 \mathrm{~s}$;

Sinusoidal, uniform and stable in time mean-variant component is visible.

\section{DETECTION OF THE RESONANCE OF THE SWASH-PLATE MAIN BEARING}

The formation of the resonance of the rolling elements of rolling bearings has been well and comprehensively described in the studies $[3,5,8$ 10]. It can only be recalled that for the resonance of a rolling bearing to occur, optimal radial clearances are necessary. It manifests itself in the rhythmic elastic bouncing of the rolling elements between the raceways. It is significant here that these impacts occur at the same points on the running track. These impacts thus create as many flaking surfaces of the running track as there are in total the rolling elements. The interaction of the basket-separator is very important then, as it reduces the energy of elements moving too quickly and increases the energy of too slow elements. In the places of the first exfoliation, the so-called " attraction pools" [8, 9-10] and the process of further exfoliation is accelerated. A very important parameter concerning the resonance of a rolling bearing which determines its possible disqualification is the so-called vibrations quality of and their amplitude. Usually, in the process of bearing destruction in the process of resonant vibrations, the amplitude is first increased, then after the formation of the first exfoliation 
("attraction pools"), the vibration goodness begins to increase. The amplitude of mechanical vibrations in the FAM-C method reflects the height of the characteristic set. The quality of mechanical vibrations is obtained from the formula:

$$
\mathrm{Q}=f_{\mathrm{oj}} / \Delta f_{\mathrm{poj}}
$$

where: $\mathrm{f}_{\mathrm{oj}}$ - sub-carrier frequency of a given characteristic set, $\Delta \mathrm{f}_{\text {poj }}$ - bandwidth occupied by a given characteristic set.

The resonance of the upper bearing (as well as other rolling bearings) is manifested in the FAM-C method in the band reserved for the abovementioned bearing (e.g. for the Mi-24 helicopter this band is within the limits of $165 \div 250 \mathrm{~Hz}$ ) - Fig. 15: a) the height of the characteristic set decreses; b) the set breaks down into 2 or more subsets.
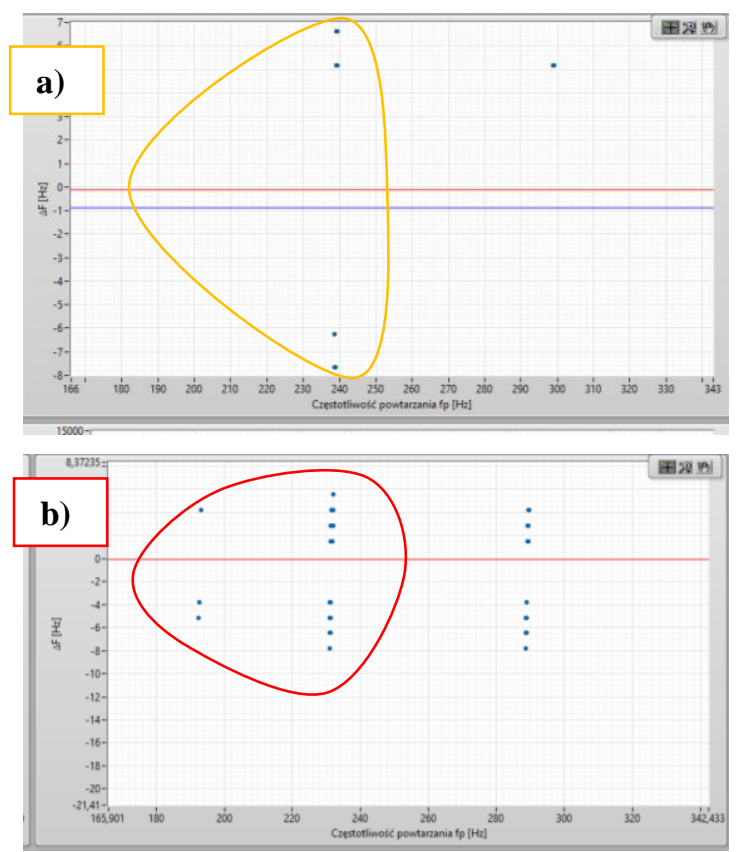

Fig. 15. Characteristic sets (striates) of the upper bearing of the swash-plate - the rim marks the characteristic points of the upper bearing of the swash-plate in the band reserved for the abovementioned bearing: a) without resonance - a single set; $b$ ) with resonance - decay into 2 subsets

\section{CONCLUSION}

The swash-plate, according to many authors, is the most complicated component of a helicopter control system. At the same time, its most important components such as the main bearing, the tappet assembly and the synchronizer rod are subjected to heavy loads during helicopter maneuvers. This is combined with intense vibrations. The entire structure is attached only in the lower part to the helicopter structure (to the main gearbox body). Thus, the most important elements of the swashplate which are decisive for the safety of the helicopter are mounted in the upper part of this elaborate high structure in its upper part, which causes significant deflection arrows in this region. For these reasons, mounting classical piezoelectric sensors in this region is very risky. It is a region where acoustic waves from many sound sources are concentrated - the use of acoustic sensors is burdened with interference errors - they do not work here either. On the other hand, the FAM-C method, where the diagnostic sensor is an on-board electric generator, effectively detects damage to the basic mechanical components of the swash-plate. It is not only effective but also user-friendly for the technical staff, as the FAM-C apparatus can be connected to any point of the helicopter's electrical network, away from dangerous rotating elements or the zones of engines exhaust gases.

Author contributions: research concept and design, A.G., H,K., T.K., K.H., S.J.K., F.Z.; Collection and/or assembly of data, A.G., H,K., T.K., K.H., S.J.K., F.Z.; Data analysis and interpretation, A.G., H,K., T.K., K.H., S.J.K., F.Z.; Writing the article, A.G., H,K., T.K., K.H., S.J.K., F.Z.; Critical revision of the article, A.G., H,K., T.K., K.H., S.J.K., F.Z.; Final approval of the article, A.G., H,K., T.K., K.H., S.J.K., F.Z.

Declaration of competing interest: The authors declare that they have no known competing financial interests or personal relationships that could have appeared to influence the work reported in this paper.

\section{REFERENCES}

1. Ahrabian A, Looney D, Stanković L, Mandic D. Synchrosqueezing-based time-frequency analysis of multivariate data. Signal Processing 2015;106:331341. https://doi.org/10.1016/j.sigpro.2014.08.010.

2. Carington IB, Wright JR, Cooper JE, Dimitriadis G. A comparison of blade tip timing data analysis methods. Procedings of the Instituation of Mechanical Engineers, Part G, Journal of Aerospace Engineering. 2001;215(5):301-312. https://doi.org/10.1243/0954410011533293.

3. Cui L, Zhang $\mathrm{Y}$, Zhang $\mathrm{F}$, Zhang $\mathrm{J}$ and Lee $\mathrm{S}$. Vibration response mechanism of faulty outer race rolling element bearings for quantitative analysis. Journal of Sound and Vibration 2016;364:67-76. https://doi.org/10.1016/j.jsv.2015.10.015.

4. Duan F, Fang Z, Sun Y, Ye S. Real time vibration measurement technique based on tip-timing for rotating blades. Opto-Electronic Engineering, 2005; 30(1):29-31, http//www.paper.edu.cn.

5. Furmanek S, Kraszewski Z. Niezawodność łożysk tocznych. Wydawnictwa Przemysłowe WEMA, Warszawa 1989.

6. Gębura A, Pietnoczko B, Tokarski T. Diagnostic testers operating on the basis of the FAM-C method. Diagnostyka 2016;17(2): 87-94.

7. Gębura A, Stefaniuk M. Monitoring the helicopter transmission using the FAM-C diagnostic method, Diagnostyka. 2017;18(2):75-85.

8. Gębura A, Tokarski T. The monitoring of the bering nodes with excessive radial clearances using the FAM-C and FDM-A methods. Research Works of Air Force Institute of Technology. 2009;25:89-127.

9. Gębura A. Dozorowanie stanu technicznego węzłów łożyskowych i wybranych elementów transmisji zespołu napędowego $\mathrm{z}$ wykorzystaniem modulacji częstotliwości napięcia wyjściowego. Wyd. ITWL, 2014 
10. Gębura A. Four models of tribological wear of turbine jet engine bearings based on methods of electrical generator signal analysis. Diagnostyka 2017;18(1):59-66.

11. Ioan D, Viorel P, Spiridon C. The influence of the misalignment on load distribution in angular contact ball bearings. Applied Mechanics and Materials 2014;658:299-304. https://doi.org/10.4028/www. scientific.net/AMM.658.299

12. Mishra C, Samantaray AK, Chakraborty G, Zhang J, Lee S. Ball bearing defect models: A study of simulated and experimental fault signatures. Journal of Sound and Vibration 2017;400:86-112. https://doi.org/10.1016/j.jsv.2017.04.010.

13. Padfield GD. Flying qualities: forms of degradation. helicopter flight dynamics: the theory and application of flying qualities and simulation modelling. Blackwell Publishing. 2007.

14. Smagała AK. Kęcik K. Nonlinear model and simulation of a rolling bearing. CMES'19, IOP Conf. Series: Materials Science and Engineering 2019;710: 012006. https://doi.org/10.1088/1757899X/710/1/012006.

15. Warmiński J. Nieliniowe postacie drgań - układy dyskretne, Wydawnictwo Naukowe PWN, Warszawa 2011.

16. Witoś M. Increasing the durability of turbine engines through active diagnostics and control (pol.: Zwiększenie żywotności silników turbinowych poprzez aktywne diagnozowanie i sterowanie). ITWL, Warszawa, 2010: https://doi.org/10.13140/RG.2.1.4341.45.

17. Żurek J. Żywotność śmigłowców. ITWL, Warszawa 2006.

Received 2021-10-20

Accepted 2022-01-14

Available online 2022-01-19

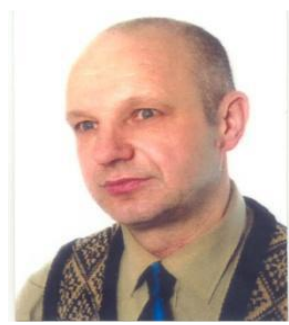

dr hab. inż. Andrzej GĘBURA, prof. ITWL - absolwent WAT na kierunku elektro-mechanika specjalność osprzęt lotniczy. Od 1985 w ITWL. Pomysłodawca i koordynator wdrażania nowatorskiej metody diagnostycznej FAM-C, w 1998 obronił w ITWL rozprawę doktorską w Instytucie Technicznym Wojsk Lotniczych. W 2019 r. otrzymał habilitację. Od 01.12.2021 r jest profesorem ITWL. Autor 117 publikacji w tym 3 monografii naukowych.

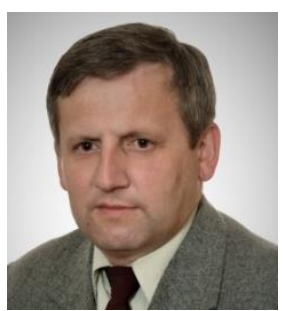

dr inż. Henryk KOWALCZYK - absolwent WAT, specjalność samoloty i śmigłowce. W roku 1996 obronił rozprawę doktorską w WAT. Wspóltwórca modernizacji śmigłowców SZ RP i autor opracowań naukowych i popularno-naukowych.

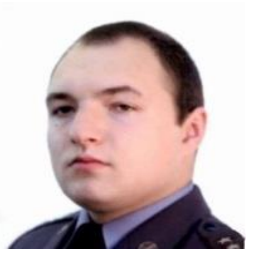

kpt. mgr inż. Kacper HANDZEL absolwent Wojskowej Akademii Technicznej, specjalność rozpoznanie i walka elektroniczna. Od 01.01.2017 służbę pełni w Instytucie Technicznym Wojsk Lotniczych jako asystent.

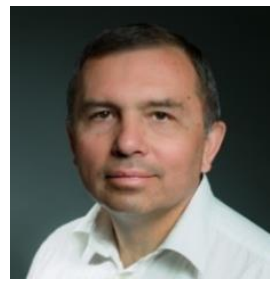

dr inż. Slawomir KLIMASZEWSKI - absolwent Wojskowej Akademii Technicznej, specjalność eksploatacja samolotów i śmigłowców. W roku 1992 obronił rozprawę doktorską w Akademii Marynarki Wojennej. Specjalizuje się z zagadnieniach związanych ze zdatnością do lotu oraz oceną niezawodności i bezpieczeństwa wojskowych statków powietrznych.

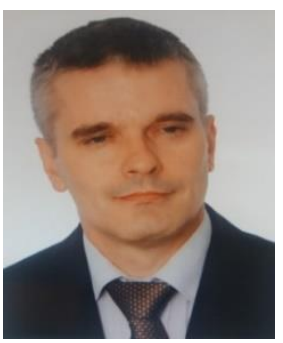

mgr inż. Tomasz TOKARSKI absolwent Politechniki Warszawskiej. Specjalista w dziedzinie elektroenergetyki, elektrotechniki, mechaniki i struktur materiałowych. Aktualnie otwarty przewód doktorski. Od 2012 r pełni obowiązki Kierownika Pracowni Osprzętu Lotniczego. Autor ponad 40 artykułów naukowych.

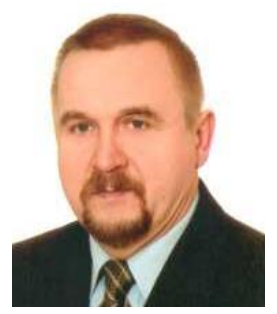

dr inż. Franciszek ZGRZYWA absolwent WAT 1985 r. Wydział Mechaniczny, specjalność samoloty i śmigłowce. Obronił doktorat $\mathrm{w}$ ITWL $\mathrm{z}$ mechaniki lotu samolotów $\mathrm{Z}$ napędem turbinowym. Autor kilkunastu opracowań naukowych. Od kilkunastu lat jest kierownikiem-koordynatorem grupy tematycznej badań awarii i wypadków lotniczych lotnictwa wojskowego. 